\title{
Potentiation of Inhibitory Synaptic Transmission by Extracellular ATP in Rat Suprachiasmatic Nuclei
}

\author{
Anirban Bhattacharya, ${ }^{1}$ Vojtech Vavra, ${ }^{1}$ Irena Svobodova, ${ }^{1}$ Zdena Bendova, ${ }^{2}$ Gyorgy Vereb,${ }^{3}$ and Hana Zemkova ${ }^{1}$ \\ ${ }^{1}$ Department of Cellular and Molecular Neuroendocrinology, Institute of Physiology of the Academy of Sciences of the Czech Republic, 14220 Prague 4 , \\ Czech Republic, ${ }^{2}$ Department of Physiology, Faculty of Science, Charles University in Prague, 11636 Prague 1, Czech Republic, and ${ }^{3}$ Department of \\ Biophysics and Cell Biology, Faculty of Medicine, Medical and Health Science Center, University of Debrecen, 4032 Debrecen, Hungary
}

The hypothalamic suprachiasmatic nuclei (SCN), the circadian master clock in mammals, releases ATP in a rhythm, but the role of extracellular ATP in the SCN is still unknown. In this study, we examined the expression and function of ATP-gated P2X receptors (P2XRs) in the SCN neurons of slices isolated from the brain of 16- to 20-day-old rats. Quantitative RT-PCR showed that the SCN contains mRNA for P2X 1-7 receptors and several G-protein-coupled P2Y receptors. Among the P2XR subunits, the P2X2 $>$ P2X7 $>$ P2X4 mRNAs were the most abundant. Whole-cell patch-clamp recordings from SCN neurons revealed that extracellular ATP application increased the frequency of spontaneous GABAergic IPSCs without changes in their amplitudes. The effect of ATP appears to be mediated by presynaptic P2X2Rs because ATP $\gamma$ S and 2MeS-ATP mimics, while the P2XR antagonist PPADS blocks, the observed enhancement of the frequency of GABA currents. There were significant differences between two SCN regions in that the effect of ATP was higher in the ventrolateral subdivision, which is densely innervated from outside the SCN. Little evidence was found for the presence of P2XR channels in somata of SCN neurons as P2X2R immunoreactivity colocalized with synapsin and ATP-induced current was observed in only $7 \%$ of cells. In fura-2 AM-loaded slices, BzATP as well as ADP stimulated intracellular $\mathrm{Ca}^{2+}$ increase, indicating that the SCN cells express functional P2X7 and $\mathrm{P} 2 \mathrm{Y}$ receptors. Our data suggest that ATP activates presynaptic P2X2Rs to regulate inhibitory synaptic transmission within the SCN and that this effect varies between regions.

\section{Introduction}

The hypothalamic suprachiasmatic nuclei (SCN) are the center of the endogenous clock that controls circadian changes in a variety of physiological and behavioral functions (Klein et al., 1991) and coordinates the peripheral oscillators (Dibner et al., 2011). In most species, including the rat, the SCN have two regions that differ in neuronal inputs and levels of the neuropeptides that mediate the rhythmic output of the SCN: the ventrolateral (VL) region receives glutamatergic inputs from the retina and produces vasoactive intestinal polypeptide (VIP), and the dorsomedial (DM) region is enriched with argininevasopressin (AVP)-containing neurons and does not receive direct photic inputs (Gillette and Reppert, 1987; Moore et al., 2002). The SCN generate a circadian rhythm through spontaneous neuronal electrical activity (Inouye and Kawamura, 1979; Brown and Piggins, 2007), 2-deoxyglucose metabolism (Schwartz et al., 1980), secretion of AVP (Schwartz and Reppert,

Received Oct. 3, 2012; revised Feb. 27, 2013; accepted March 27, 2013.

Author contributions: A.B., V.V., and H.Z. designed research; A.B., V.V., I.S., Z.B., and G.V. performed research; A.B., V.V., Z.B., and H.Z. analyzed data; H.Z. wrote the paper.

This work was supported by the Internal Grant Agency of Academy of Sciences (IAA500110910), Grant Agency of the Czech Republic (P304/12/G069), Grant CZ.1.07/2.3.00/30.0025, and the Academy of Sciences of the Czech Republic (Research Project RV0:67985823).

The authors declare no competing financial interests.

Correspondence should be addressed to Dr. Hana Zemkova, Institute of Physiology, Academy of Sciences of the Czech Republic, Vídenská 1083, 14220 Prague 4, Czech Republic. E-mail: zemkova@biomed.cas.cz.

DOI:10.1523/JNEUROSCI.4682-12.2013

Copyright $\odot 2013$ the authors $\quad 0270-6474 / 13 / 338035-10 \$ 15.00 / 0$
1985; Watanabe et al., 2000) and VIP (Shinohara et al., 1994), and the production of nitric oxide (Mitome et al., 2001) and prokineticin 2 (Cheng et al., 2002). There is also a circadian rhythm in ATP levels (Yamazaki et al., 1994) and release (Womac et al., 2009), which negatively correlates with the electrical activity and AVP secretion rhythm (Womac et al., 2009). Although the rhythm of ATP release from the SCN cells is well established (Burkeen et al., 2011), the role of ATP remains to be determined.

Extracellular ATP and its metabolic products act as agonists for adenosine and purinergic P2X and P2Y receptors (Burnstock, 1977). Purinergic P2X receptors (P2XR1-P2XR7) are ATP-gated ion channels (North, 2002), but the adenosine and P2Y receptors belong to the superfamily of G-protein-coupled receptors (Abbracchio et al., 2009). Adenosine has been shown to inhibit glutamatergic retinohypothalamic neurotransmission via presynaptic adenosine A1 receptors in the SCN of hamster (Hallworth et al., 2002) and mouse (Sigworth and Rea, 2003). P2XRs are highly expressed throughout the hypothalamus (Collo et al., 1996; Vulchanova et al., 1996; Kanjhan et al., 1999; Guo et al., 2009), where ATP, coreleased with neuropeptides, appears to be involved in the regulation of hormone secretion (Troadec et al., 1998; Kapoor and Sladek, 2000; Stojilkovic, 2009) and control of specific autonomic functions, including the central mechanism of body temperature regulation (Gourine et al., 2002), for example. The expression of $P 2 X 2, P 2 X 4$, and $P 2 X 6$ receptor mRNAs (Collo et al., 1996) and the P2X5R protein (Xiang et al., 2006) has also been found in the rat SCN; however, there is no information available regarding other P2XR subtypes and the function of these receptors in the SCN. 
We have investigated this issue through the use of qRT-PCR analysis, immunohistochemistry, patch-clamping, and calcium imaging. As a first step, we determined the mRNA expression levels for P2X1-7 and several P2Y receptors and examined the effect of ATP on membrane potentials and currents recorded from SCN slices. Comparisons were made between regions of the SCN. Finally, the effects of agonists and antagonists of P2XRs on SCN cells were determined.

\section{Materials and Methods}

Animals and brain slices. The Animal Care and Use Committee of the Academy of Sciences of the Czech Republic approved the experiments of the present study. Experiments were performed in 14- to 24-day-old Wistar rats, which were kept under a controlled 12-12 h light-dark cycle from birth. Animals had lights on from 6:00 A.M. to 6:00 P.M. Brains were removed between 11:00 A.M. and 6:00 P.M. after decapitation and placed into ice-cold $\left(4^{\circ} \mathrm{C}\right)$ oxygenated $\left(95 \% \mathrm{O}_{2}+5 \% \mathrm{CO}_{2}\right)$ artificial CSF (ACSF). Hypothalamic slices (200- to $300-\mu \mathrm{m}$-thick) containing SCN were cut with a vibratome (DTK-1000, D.S.K. Dosaka) and incubated as described previously (Kretschmannova et al., 2003; Vavra et al., 2011). Briefly, the slices were allowed to recover for at least $1 \mathrm{~h}$ in oxygenated ACSF at $32^{\circ} \mathrm{C}-33^{\circ} \mathrm{C}$ before being transferred into a recording chamber. During the experiments, slices were fixed with a platinum U-shaped wire to the bottom of the chamber and submerged in continuously flowing oxygenated ACSF at $1-2 \mathrm{ml} / \mathrm{min}$ at room temperature. Slices were viewed with an upright microscope (BX50WI, Olympus) mounted on a Gibraltar movable X-Y platform (Burleigh) using water-immersion lenses $(60 \times$ and $10 \times)$ and Dodt infrared gradient contrast (Luigs \& Neumann). SCN regions were identified by their position relative to the third ventricle and the optic chiasm in a coronal hypothalamic section (see Fig. 1A).

Cell cultures. The SCN regions were dissected from $\sim 600-\mu \mathrm{m}$-thick hypothalamic slices, and the cells were dissociated after treatment with trypsin according to the published method (Watanabe et al., 1993). Next, the cells were purified on discontinuous protein gradient, $\sim 100,000$ cells were placed on coverslips coated with $1 \%$ poly-L-lysine solution (Sigma) in $35 \mathrm{~mm}$ culture dishes (BD Falcon) and cultured in Neurobasal medium with $2 \%$ B27 supplement and $0.5 \mathrm{~mm}$ L-glutamine (all from Invitrogen) in a humidified $\mathrm{CO}_{2}$-containing atmosphere at $37^{\circ} \mathrm{C}$ until the use $(7 \mathrm{~d})$.

Immunohistochemistry. Adult male Wistar rats were deeply anesthetized by intraperitoneal injection of thiopental $(50 \mathrm{mg} / \mathrm{kg}$, Valeant Czech Pharma) and perfused through the ascending aorta with heparinized saline followed by PBS ( $0.01 \mathrm{M}$ sodium phosphate $/ 0.15 \mathrm{M} \mathrm{NaCl}, \mathrm{pH} 7.2)$, and then with $4 \%$ paraformaldehyde in PBS. Brains were removed, postfixed for $12 \mathrm{~h}$ at $4^{\circ} \mathrm{C}$, cryoprotected in $20 \%$ sucrose in PBS overnight at $4^{\circ} \mathrm{C}$, frozen on dry ice, and stored at $-80^{\circ} \mathrm{C}$. Frozen brains were sectioned into a series of $30-\mu \mathrm{m}$-thick free-floating coronal sections. Nonspecific reactions were blocked by incubation of sections in blocking buffer: $2 \%$ normal donkey serum, 1\% BSA, 0.5\% Triton X-100 in PBS, for $2 \mathrm{~h}$. After blocking, sections were probed by incubation with primary antibodies (anti-P2X2R, Alomone; anti-NeuN, Merck Millipore; anti-GFAP, Merck Millipore) overnight, and detected afterward with secondary antibodies (AlexaFluor-488, Invitrogen; TRITC, Merck Millipore; Cy5, Merck Millipore). Primary cell cultures were fixed in $4 \%$ paraformaldehyde for 10 min, washed in PBS, blocked in PBS/serum for $1 \mathrm{~h}$, and incubated with anti-P2X2R antibodies overnight. The next day, cell were incubated with anti-synapsin I antibody (BD Biosciences) for $2 \mathrm{~h}$, followed by mix of secondary antibody conjugated with AlexaFluor-488 and AlexaFluor633 (Invitrogen). Cell nuclei were counterstained by DAPI included in mounting medium (Invitrogen). The images were collected and analyzed using confocal microscope Leica TCS SP2.

Patch-clamp recordings. ATP-induced currents and membrane potentials were recorded from SCN slices using standard whole-cell patchclamp techniques with an Axopatch-200B amplifier (Molecular Devices). Patch pipettes were pulled on the horizontal Flaming Brown P-97 model puller (Sutter Instruments) from borosilicate glass (World Precision Instruments) and polished by heat to a tip resistance of 4-6
$\mathrm{M} \Omega$. The access resistance (average $11 \pm 2 \mathrm{M} \Omega$ ) was monitored throughout each experiment. The mean capacitance of the cells was $6-8 \mathrm{pF}$, $50-80 \%$ series resistance compensation was used, and liquid junction potential $(\sim 4 \mathrm{mV})$ was corrected when determining the resting membrane potential of SCN cells. Data were captured and stored using the pClamp 9 software package in conjunction with the Digidata 1322A A/D converter (Molecular Devices). Signals were filtered at $1 \mathrm{kHz}$ and sampled at $2 \mathrm{kHz}$ if not otherwise stated. The cell membrane potential was held at $-60 \mathrm{mV}$.

Drug application. ATP, $\gamma$-aminobutyric acid (GABA), and drugs were applied in a HEPES-buffered extracellular solution (see Solutions) using a fast gravity-driven microperfusion system made in our laboratory (Dittert et al., 2006). This application system consists of nine glass tubes, each $\sim 400 \mu \mathrm{m}$ in diameter, with a common outlet of $\sim 300 \mu \mathrm{m}$ in diameter. The application tip was routinely positioned at $\sim 500 \mu \mathrm{m}$ distance from the recorded cell and $\sim 50 \mu \mathrm{m}$ above the surface of the slice, and the solution application was controlled by microcomputer and miniature Teflon solenoid valves (General Valves). The washout time between each ATP application was $2-5$ min.

Calcium imaging. For intracellular $\mathrm{Ca}^{2+}$ fluorescence imaging, acutely isolated rat brains slices containing SCN were incubated for at least $1 \mathrm{~h}$ in oxygenated ACSF at $32^{\circ} \mathrm{C}-33^{\circ} \mathrm{C}$. Slices were placed on $5 \times 5 \mathrm{~mm}$ nylon lattice on the bottom of a culture dish and incubated in $2 \mathrm{ml}$ ACSF containing $1 \mu \mathrm{M}$ of the membrane-permeant ester form of fura-2 (fura-2 $\mathrm{AM}$, Invitrogen) and $0.15 \%$ dispersing agent Pluronic F-127 for the next $1 \mathrm{~h}$ in carbogen atmosphere $\left(95 \% \mathrm{O}_{2}\right.$ and $\left.5 \% \mathrm{CO}_{2}\right)$. After $15 \mathrm{~min}$ of washing in fresh ASCF, fura-2 fluorescence from single cells on the slice surface was measured using a MicroMAX CCD camera (Princeton Instruments) and an Olympus BX50WI epifluorescent microscope coupled to a monochromatic illumination system (T.I.L.L., Photonics). Hardware control and image analysis were performed using MetaFluor software (Molecular Devices). Cells were examined under a waterimmersion objective during exposure to alternating 340 and $380 \mathrm{~nm}$ light beams. The emitted light images at $515 \mathrm{~nm}$ were acquired through a $10 \times$ $0.1 \mathrm{NA}$ (whole SCN) and $40 \times 0.9 \mathrm{NA}$ (cells) objective, and the intensity of light emission was measured. The ratio of light intensity $\left(\mathrm{F}_{340} / \mathrm{F}_{380}\right)$ reflects changes in intracellular calcium concentration $\left(\left[\mathrm{Ca}^{2+}\right]_{i}\right)$ and was followed in several single cells simultaneously at the rate of one point per second.

Solutions. Slices were preincubated at $32^{\circ} \mathrm{C}-33^{\circ} \mathrm{C}$ in oxygenated ACSF that contained the following: $130 \mathrm{~mm} \mathrm{NaCl}, 3 \mathrm{~mm} \mathrm{KCl}, 1 \mathrm{~mm} \mathrm{MgCl}_{2}, 2$ $\mathrm{mm} \mathrm{CaCl}_{2}, 19 \mathrm{~mm} \mathrm{NaHCO}_{3}, 1.25 \mathrm{~mm} \mathrm{NaH}_{2} \mathrm{PO}_{4}$, and $10 \mathrm{~mm}$ glucose $(\mathrm{pH}$ 7.3-7.4; osmolality 300-315 mOsm). Drugs were diluted and applied in a HEPES-buffered extracellular solution containing the following: 142 $\mathrm{mm} \mathrm{NaCl}, 3 \mathrm{~mm} \mathrm{KCl}, 1 \mathrm{~mm} \mathrm{MgCl}, 2 \mathrm{~mm} \mathrm{CaCl}_{2}, 10 \mathrm{~mm}$ glucose, and 10 mM HEPES, pH adjusted to 7.3 with $1 \mathrm{~m} \mathrm{NaOH}$; osmolality was $300-315$ mOsm. Patch electrodes used for whole-cell recording were filled with an intracellular solution containing the following: $140 \mathrm{~mm} \mathrm{KCl,} 3 \mathrm{~mm}$ $\mathrm{MgCl}_{2}, 0.5 \mathrm{~mm} \mathrm{CaCl}_{2}, 10 \mathrm{~mm}$ HEPES, and $5 \mathrm{~mm}$ EGTA, pH adjusted to 7.2 with $\mathrm{KOH}$. The osmolality of the intracellular solutions was 285-295 mOsm.

Quantitative real time RT-PCR. Coronal hypothalamic slices (200-250 $\mu \mathrm{m})$ containing SCN were dissected from rat brains using a Vibratome slicer. SCN were punched out of the slices under visual control (magnification $20 \times$ ) using a needle punch with an internal diameter of $\sim 1 \mathrm{~mm}$. Samples were either used immediately or frozen in RNAlater (SigmaAldrich) at $-80^{\circ} \mathrm{C}$. Samples were homogenized using ceramic balls (MagNA Lyser Green Beads) and a MagNA Lyser homogenizer (Roche Diagnostics). Total RNA was extracted from homogenized tissue using column isolation with a GenElute Mammalian Total RNA Miniprep Kit (Sigma-Aldrich) according to the manufacturer's protocol. The concentration of total RNA in each sample was measured using a NanoDrop spectrophotometer (Thermo Fisher Scientific). Samples were volume adjusted with DNAase- and RNAase-free DEPC-treated water provided with the RT kit and normalized for their RNA content. First-strand cDNA was synthesized from up to $1 \mu \mathrm{g}$ of RNA using a Superscript III first-strand synthesis supermix for qRT-PCR (Invitrogen). Random hexamers provided with the kit were used as the primers for reverse transcription. Expression levels of specific mRNA(s) for P2X receptors 1-7 
(P2X1-P2X7) and P2Y1, 2, and 12 genes were measured using ABI PRISM 7000 Sequence Detection System (Applied Biosystems). The probes and primers (TaqMan inventoried probes) used for these experiments were developed by Applied Biosystems as TaqMan Gene Expression assay, specifically the following: P2X1 (Rn00564454_m1), P2X2 (Rn00586491_m1), P2X3 (Rn00579301_m1), P2X4 (Rn00580949_m1), P2X5 (Rn00589966_m1), P2X6 (Rn00562354_m1), P2X7 (Rn00570451_ m1), P2Y1 (Rn00562996_m1), P2Y2 (Rn00568476_m1), P2Y12 (Rn00575653_m1), and GAPDH (TaqMan Endogenous Control, catalog \#4352338E). Real-time PCR amplification reactions were performed in $30 \mu \mathrm{l}$ aliquots on a 96-well optical plate in a duplex reaction format. Each reaction contained TaqMan target gene probes labeled with FAM/ TAMRA, GAPDH probes (VIC/MGB), TaqMan Gene Expression Master Mix with AmpErase UNG (Applied Biosystems) and cDNA. Genespecific calibration curves were generated from serial dilutions of standard cDNA to determine the efficiency of individual probes for target genes along with the "housekeeping" gene GAPDH. The efficiency of different probes was found to be very similar, and the $2^{-\Delta \Delta} C_{T}$ method was used to calculate the mRNA levels of all genes of interest normalized to the reference gene (GAPDH).

Data analysis. The frequencies and amplitudes of spontaneous postsynaptic currents were manually analyzed off-line using a pClamp 10 (Molecular Devices). The currents were detected using a threshold-based event search and visually evaluated by the experimenters. Only events exceeding $10 \mathrm{pA}$ were used in subsequent analysis. The amplitudes of individual events were determined by the detection program. Frequency was calculated from number of events over the recording time. Statistical comparisons were made using Student's paired $t$ test in SigmaPlot (Systat Software). All values are reported as mean \pm SEM. Significance was defined as $p<0.01$ and $p<0.05$. Graphing was performed using SigmaPlot (Systat Software) and CorelDraw (Corel) software.

Chemicals. Pyridoxalphosphate-6-azophenyl-2',4'-disulfonic acid (PPADS), suramin, 6,7-dinitroquinoxaline-2,3-dione (DNQX), 2amino-5-phosphonopentanoic acid (AP5), and 2'-deoxy- $N^{6}$-methyladenosine 3',5'-bisphosphate tetrasodium salt (MRS 2179) were purchased from Tocris Bioscience-Cookson. Fura 2-AM was from Invitrogen. ATP, ADP, 2-methylthio AMP (2MeS-AMP), 2-methylthio ADP (2MeS-ADP), 2-methylthio ATP (2MeS-ATP), $\alpha \beta$-methylene ATP $(\alpha \beta$ meATP), adenosine 5'-O-(2-thiotriphosphate) (ATP $\gamma S), 2^{\prime}-3^{\prime}$-O-(4benzoylbenzoyl)-ATP (BzATP), TTX, and all other drugs and chemicals were from Sigma. Suramin and PPADS (P2X receptor inhibitors) were used at $10 \mu \mathrm{M}$ from a $10 \mathrm{~mm}$ working stock in DMSO; hence, $0.1 \%(\mathrm{v} / \mathrm{v})$ DMSO vehicle controls were applied in parallel to suramin and PPADS incubations.

\section{Results}

Expression of $\mathrm{mRNA}$ and protein for purinergic $\mathrm{P} 2$ receptors in the SCN

We first performed qRT-PCR analysis using pools of mRNAs from rat hypothalamic samples containing the SCN (Fig. 1A). We examined the expression of the purinergic $\mathrm{P} 2 \mathrm{X} 1-7$ receptor and three $\mathrm{P} 2 \mathrm{Y}$ receptors (P2Y1, P2Y2, and P2Y12). Figure $1 B$ shows the mean \pm SEM data from three independent experiments. The SCN samples expressed all P2XR subunits, and the quantities of the subunits followed the order $P 2 X 2>P 2 X 7>P 2 X 4>P 2 X 5>P 2 X 1=P 2 X 3$; the amount of $P 2 X 6$ mRNA was low. The mRNA transcripts for P2YRs were also identified in the SCN samples, and the quantities of the subunits were in the order P2Y2 $>P 2 Y 1>P 2 Y 12$.

Next, we analyzed the rat SCN slices and the SCN cell cultures using immunohistochemical staining for the P2X2R, the most abundantly expressed P2X subunit in the SCN. Figure $2 A$ (top row) shows that the P2X2R expression is absent on cell bodies of SCN neurons. To demonstrate the specificity of the P2X2R antibody, we performed parallel experiments on slices containing supraoptic nuclei (SON), which are known to express functional P2X2Rs (Collo et al., 1996; Vulchanova et al., 1996; Vavra et al., 2011). A large number of cell bodies throughout the SON was
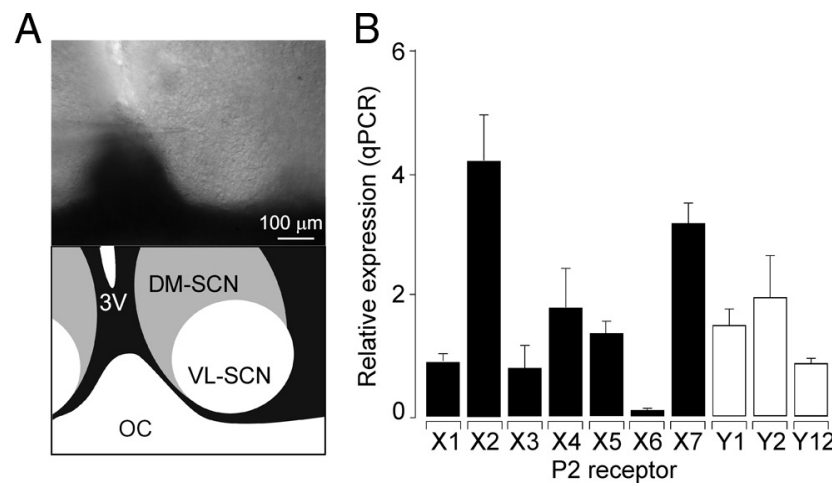

Figure 1. Quantitative expression of $\mathrm{P} 2 \mathrm{X}$ and $\mathrm{P} 2 \mathrm{Y}$ transcripts in the SCN. $\boldsymbol{A}$, The surface of a hypothalamic slice containing SCN as viewed in visible light (10X; top) and its illusory boundaries according to which the dorsomedial (DM) and ventrolateral $(\mathrm{VL})$ regions were identified (bottom). OC, Optic chiasm; 3V, third ventricle. B, qRT-PCR (qPCR) analysis and detection of seven P2X (black columns) and three P2Y (white columns) mRNA transcripts in hypothalamic tissues from 16-day-old rats. Total mRNA was isolated from six punctures containing SCN. Receptor expression was related to the expression of GAPDH as a housekeeping gene.

intensely stained for the P2X2R (Fig. $2 A$, bottom row). In the SCN cell culture, P2X2R immunoreactivity was colocalized with the presynaptic marker synapsin I (Fig. 2B). As not all the terminals labeled by the synapsin I antibody were found to be immunoreactive for the $\mathrm{P} 2 \mathrm{X} 2 \mathrm{R}$, it is clear that the receptor is not expressed in all nerve terminals.

Together, these results indicate that SCN have the capacity to express both P2XRs and P2YRs at the mRNA level. Among the P2 receptor subunits, the $P 2 X 2 \mathrm{mRNA}$ is most highly expressed and the corresponding $\mathrm{P} 2 \mathrm{X} 2 \mathrm{R}$ protein colocalizes with synapsin I in nerve endings but is generally absent on SCN somata.

\section{Effect of ATP on membrane potentials and currents in SCN neurons in slices}

To examine the effect of ATP on membrane potentials and currents in SCN neurons of freshly isolated hypothalamic slices, whole-cell patch-clamp recordings from a total 139 neurons were performed. In current-clamp mode, the brief application (10-20 s) of ATP $(100 \mu \mathrm{M})$ had no effect on resting membrane potential but increased the frequency of action potentials in $42 \%$ of SCN neurons ( 5 of 12 cells; Fig. $3 A$ ). In cells voltage-clamped at $-60 \mathrm{mV}$, ATP had two different effects: it both increased the frequency of spontaneous postsynaptic currents in $40 \%$ of SCN neurons ( $n=56$; Fig. $3 B$, left) and induced an inward current of $15 \pm 5$ pA (Fig. $3 C$ ) in $7 \%$ of SCN neurons $(n=10)$. The action resulting from ATP application exhibited a fast onset and fast offset, indicating the stimulation of $\mathrm{P} 2 \mathrm{X}$ receptor channels. All SCN neurons responded to the application of GABA $(100 \mu \mathrm{M})$ by an inward current of $852 \pm 102 \mathrm{pA}(n=6$, Fig. $3 B$, right $)$. The measurements were performed both in the VL and DM subdivisions of the SCN that could be determined according to the vicinity of chiasma and the third ventricle, respectively (Fig. 1A). Both the ATP-induced increase in the frequency of spontaneous synaptic currents and the ATP-induced inward current were observed more frequently in the VL than in the DM region of the SCN (Fig. 3D).

\section{Characterization of spontaneous EPSCs and IPSCs in the SCN}

Synaptic transmission in the SCN is mediated by the release of glutamate (Jiang et al., 1995; Peytevin et al., 2000) and GABA (Kim and Dudek, 1992; van den Pol, 1993; Moore et al., 2002). 
Under our experimental conditions (intracellular $\left[\mathrm{Cl}^{-}\right], 144 \mathrm{~mm}$; extracellular $\left[\mathrm{Cl}^{-}\right], 151 \mathrm{~mm}$; holding potential, -60 $\mathrm{mV}$ ), both spontaneous glutamatergic EPSCs (sEPSCs) and spontaneous GABAergic IPSCs (sIPSCs) could be observed as small inward currents in the postsynaptic neuron (Fig. $4 A)$. Using bicuculline $(3 \mu \mathrm{M})$ to block GABAergic currents, DNQX (20 $\mu \mathrm{M})$ to block AMPA currents, and AP5 $(50 \mu \mathrm{M})$ to block NMDA currents, we found that sEPSCs and sIPSCs differed in their amplitudes and duration. The amplitude of GABAergic sIPSCs was $183 \pm$ $27 \mathrm{pA}$, and the duration was $115 \pm 11 \mathrm{~ms}$ ( $n=9$ cells). The amplitude of the glutamatergic synaptic currents was $26 \pm 3 \mathrm{pA}$, and the duration was $7.8 \pm 0.2 \mathrm{~ms}(n=11$ cells). The sIPSCs were observed in all SCN neurons ( $n=139$ cells), whereas the sEPSCs were detected in only $8 \%$ of neurons $(n=11)$. The ATP-induced effect was completely inhibited by bicuculline in all cells examined ( $n=3$; Fig. $4 B$ ), indicating that the ATP-evoked spontaneous synaptic currents were dependent on the activation of the GABA-A receptor. However, inhibition by DNQX + AP5 failed to inhibit the ATP-induced response $(n=3$; Fig. $4 C)$. Therefore, the sEPSCs were not studied further.

\section{Regional difference in the presynaptic effect of ATP}

To determine whether the effect of ATP on SCN synaptic activity is the result of presynaptic or postsynaptic (or both) mechanisms, spontaneous transmitter release was studied in the presence of TTX, which inhibits action potentials. The absence of changes in the spontaneous postsynaptic current amplitude and an increase in frequency would argue for presynaptic mechanisms, whereas an increase in amplitude would argue for postsynaptic mechanisms. The measurements were performed both in the VL and DM subdivisions of the SCN (Fig. 5).

The frequency of baseline spontaneous GABAergic IPSCs was higher in the DM than in the VL region (Fig. $5 A, D$ ), both in the presence and absence of TTX (Fig. $5 B, E$ ). The addition of TTX (1 $\mu \mathrm{M}$ ) reduced the frequency of sIPSCs in the VL by $60 \%$ (control, $2.46 \pm 0.93 \mathrm{~Hz}$; TTX, $0.98 \pm 0.21 \mathrm{~Hz} ; n=5 ; p<0.01$; Fig. $5 B$ ) and in the DM region by $40 \%$ (control, $3.90 \pm 0.85 \mathrm{~Hz}$; TTX, $2.28 \pm 0.46 \mathrm{~Hz} ; n=12 ; p=0.014$; Fig. $5 E$ ) without affecting the amplitude of sIPSCs (Fig. 5C,F). The application of ATP was found to increase the sIPSC frequency but not other properties of sIPSCs. ATP augmented the sIPSC frequency in 58\% of VL neurons ( 26 of 45 cells) by $836 \pm 195 \%$ (control, $1.25 \pm 0.25 \mathrm{~Hz}$; ATP, $5.8 \pm 0.9 \mathrm{~Hz}, p<0.01$; Fig. $5 A, B$ ); five of these cells also exhibited ATP-induced inward current (Fig. 3D). No effect from ATP was observed in the remaining 19 VL cells (control, $3.0 \pm$ $0.74 \mathrm{~Hz}$; ATP, $3.12 \pm 0.9$. Hz; $n=19$ ). In the DM region, ATP increased the sIPSC frequency in $21 \%$ of neurons ( 6 of 28 cells) by $302 \pm 141 \%$ (control, $2.1 \pm 0.8 \mathrm{~Hz}$; ATP, $5.0 \pm 1 . \mathrm{Hz}, p<0.01$; Fig. $5 D, E)$ and no inward current was observed (Fig. $3 D$ ). The remaining 22 cells were ATP-insensitive (control, $3.3 \pm 0.6 \mathrm{~Hz}$; ATP, $3.4 \pm 0.8 \mathrm{~Hz}$ ). The application of ATP had no effect on the amplitude of sIPSCs in either the DM (control, $36 \pm 6$ pA; ATP,
A
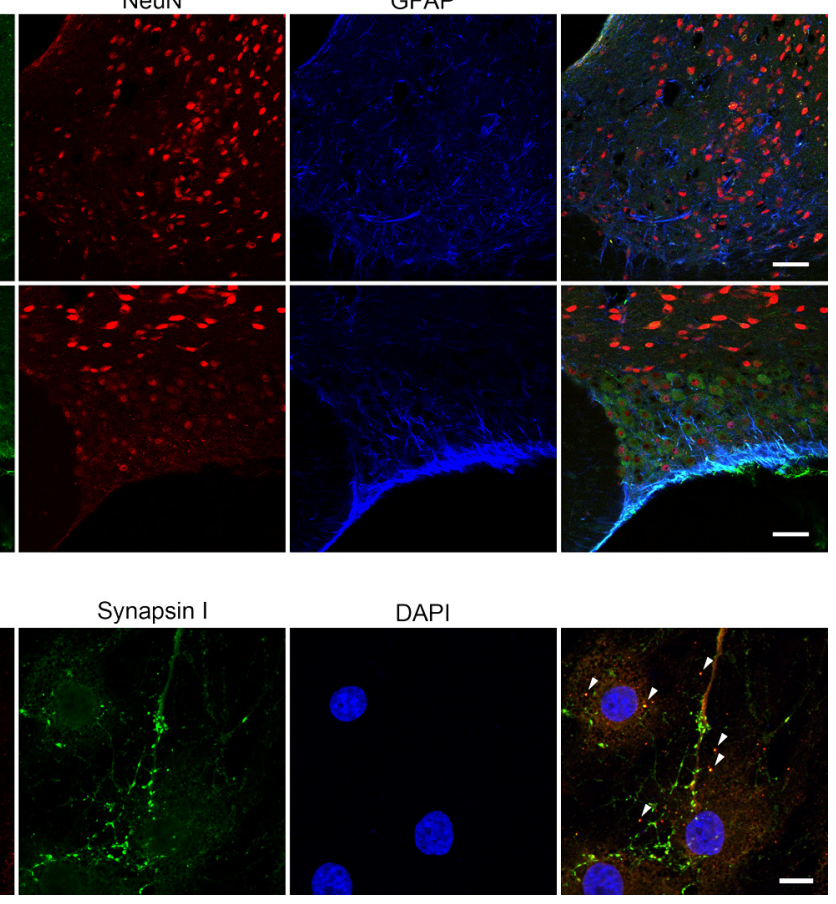
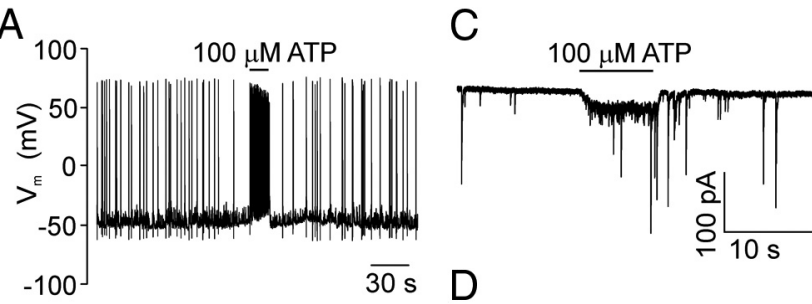

B
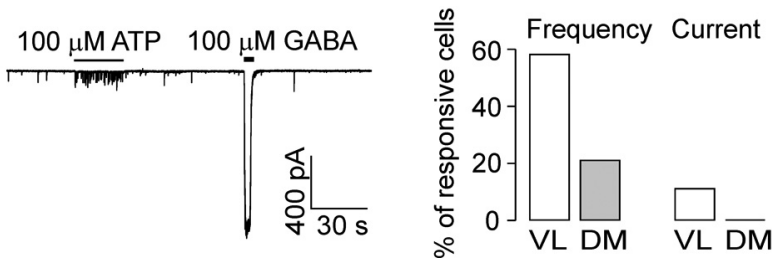

Figure 3. Effects of ATP application on membrane potentials and currents in SCN slices. $\boldsymbol{A}$ Current-clamp whole-cell recording of membrane potential from SCN neuron in slices before, during, and after the application (bar) of $100 \mu \mathrm{M}$ ATP. The ATP-induced increase in frequency of action potentials is the result of increased frequency of depolarizing GABAergic currents, which is caused by composition of our intracellular solution (see Materials and Methods). $\boldsymbol{B}$, Representative responses to an application of ATP $(100 \mu \mathrm{m})$ and GABA $(100 \mu \mathrm{M})$. ATP induced an increase in the frequency of spontaneous synaptic currents, and GABA stimulated an inward current. C, Representative record of ATP-induced inward current. All voltage-clamp recordings in this and subsequent figures were obtained in the presence of $\operatorname{TXX}(1 \mu \mathrm{m})$ from SCN neurons voltage-clamped at $-60 \mathrm{mV}$. D, Summary histograms showing the percentage of ATP-responsive cells in two subdivisions of the $\mathrm{SCN}$, ventrolateral (VL) and dorsomedial (DM). ATP induced increases in the frequency of spontaneous synaptic currents (Frequency) and the inward current (Current).

$34 \pm 5 \mathrm{pA} ; n=12$; Fig. $5 F$ ) or the VL region (control, $33 \pm 03 \mathrm{pA}$; ATP, $29 \pm 3$ pA; $n=19$; Fig. $5 C$ ). In the absence of TTX, the ATP-induced effect was lower (increase by $335 \pm 49 \% ; n=4$, VL region), but the sIPSC frequency seen after ATP application was 
A
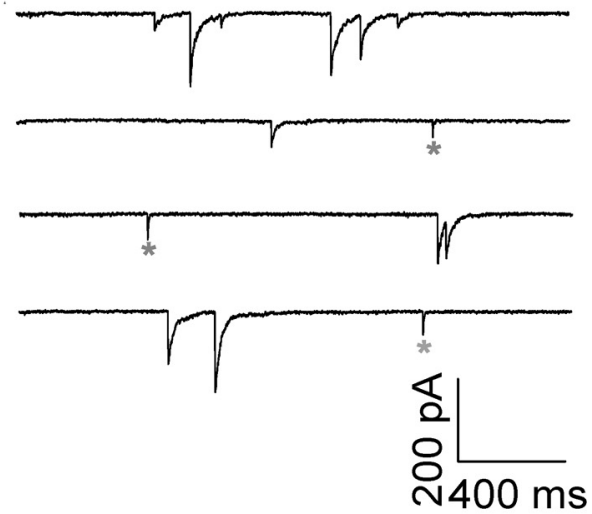

B

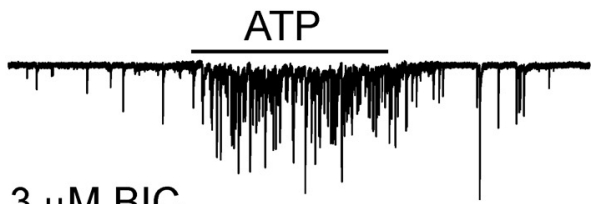

$3 \mu \mathrm{M} \mathrm{BIC}$

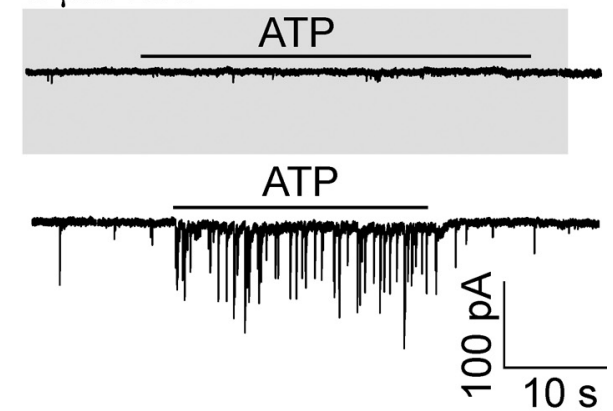

C

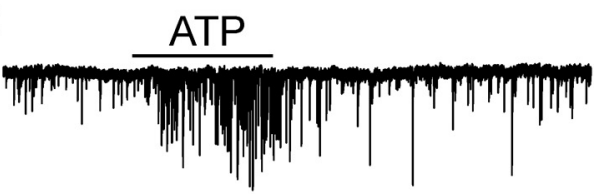

$20 \mu \mathrm{M} D \mathrm{DQX}+50 \mu \mathrm{M}$ AP5

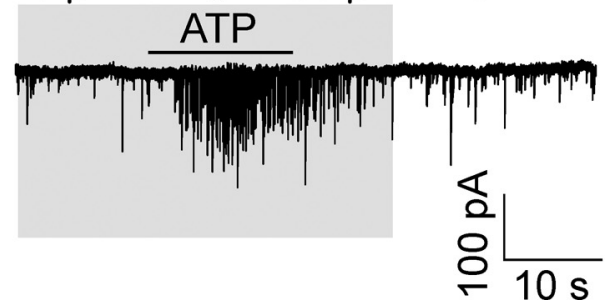

Figure 4. Effect of GABAergic or glutamatergic blockers on spontaneous synaptic currents and ATP responses. $\boldsymbol{A}$, Traces in an expanded time scale show spontaneous GABAergic and glutamatergic synaptic currents recorded from $\mathrm{SCN}$ neurons in slices. *Spontaneous glutamatergic synaptic currents. $\boldsymbol{B}$, Application of bicuculline (BIC, $3 \mu \mathrm{m}$ ) inhibited GABA currents and the ATP (100 $\mu \mathrm{m})$-induced response. ATP was applied three times in one cell, once in the presence of BIC. The time between each ATP application was $3-5$ min to allow recovery from BIC-induced inhibition ( $75 \pm 15 \%$ recovery after $4 \mathrm{~min})$. C, In the presence of DNQX $(20 \mu \mathrm{m})$ and AP5 $(50 \mu \mathrm{m})$, GABA currents persisted, and no attenuation of ATP-evoked response was observed (records in one cell). Horizontal bars above traces and gray areas indicate duration of the drug treatment. Signals were filtered at $10 \mathrm{kHz}$ and sampled at $20 \mathrm{kHz}(\boldsymbol{A})$.

not statistically different $(5.1 \pm 0.5 \mathrm{~Hz}, n=4)$ from that seen in the presence of TTX $(5.8 \pm 0.9 \mathrm{~Hz}$, see above $)$.

The ATP-evoked increase in the frequency of sIPSCs was observed starting with a threshold concentration at $30 \mu \mathrm{M}$ (Fig. $6 A, B)$, and the effective ATP concentration producing a halfmaximal effect $\left(\mathrm{EC}_{50}\right)$ was $62 \pm 24 \mu \mathrm{M}$ (Fig. $6 \mathrm{C}$ ).
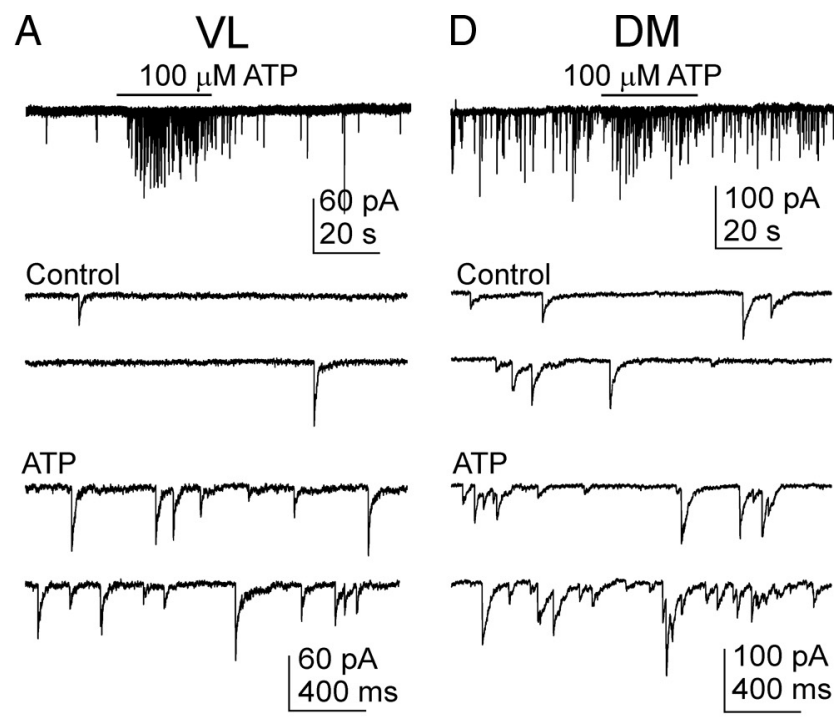

B
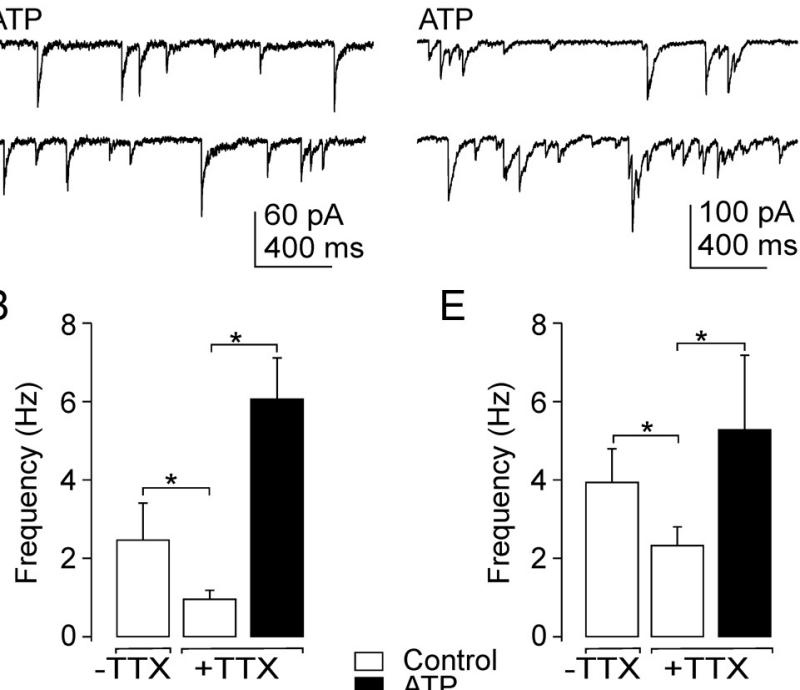

$E$
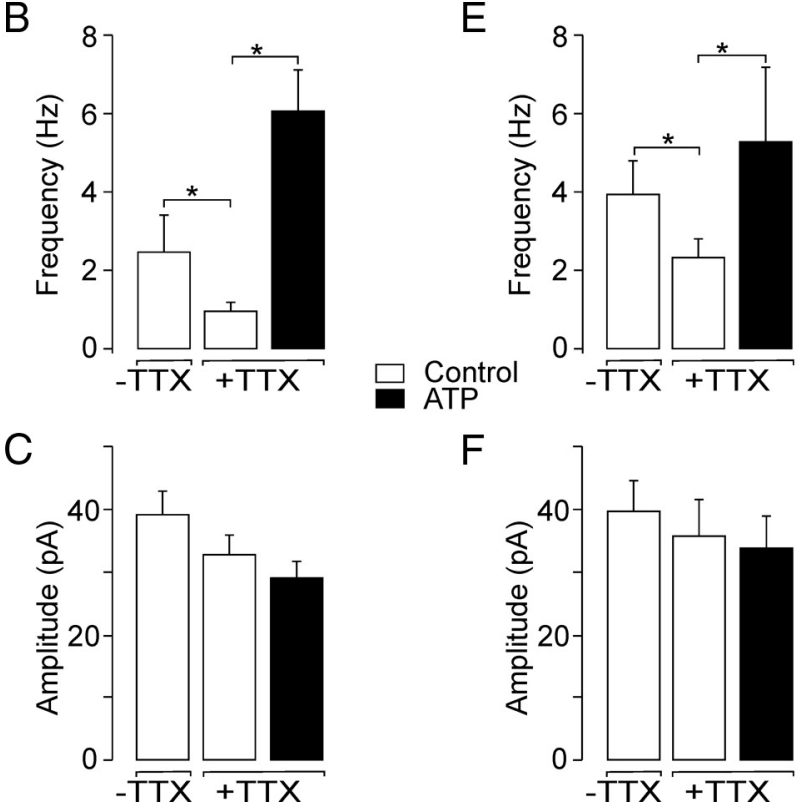

Figure 5. Regional difference in the presynaptic effect of ATP. A, ATP (100 $\mu \mathrm{M})$ induced increases in the frequency of sIPSCS in the VL region. Traces in an expanded time scale show sIPSCs before (Control) and after ATP application (ATP). B, C, Summary histograms showing the effect of TTX and ATP on the frequency ( $\boldsymbol{B})$ and amplitude $(\boldsymbol{C})$ of sIPSCs in the VL. D, ATP $(100 \mu \mathrm{m})$ induced increases in the frequency of $S$ IPSCS in the DM. $\boldsymbol{E}, \boldsymbol{F}$, Summary histograms showing the effect of TTX and ATP on the frequency $(\boldsymbol{E})$ and amplitude $(\boldsymbol{F})$ of sIPSCs in the DM. Data are mean \pm SEM from 5 to 26 cells. ${ }^{*} p<0.01$.

These results indicate that ATP acts on presynaptic receptors to stimulate GABA release and that this effect varies between regions.

Pharmacological characterization of presynaptic P2X receptors in the SCN

To determine the types of purinergic $\mathrm{P} 2$ receptors that mediated the ATP-evoked GABA release, we used specific agonists and antagonists. We first tested the involvement of P2XRs in the mediation of the effect of ATP. The P2X7R agonist, BzATP (300 $\mu \mathrm{M}$ ), failed to increase the frequency significantly (control, $2.1 \pm 0.3 \mathrm{~Hz}$; BzATP, $2.4 \pm 0.9 \mathrm{~Hz}, n=3, p>0.05$; Fig. $7 A$ ). The application of the ATP analogs 2-methylthioATP (2MeS-ATP; $100 \mu \mathrm{M})$ and adenosine 5'-O-(2-thiotriphosphate) (ATPgS; 100 

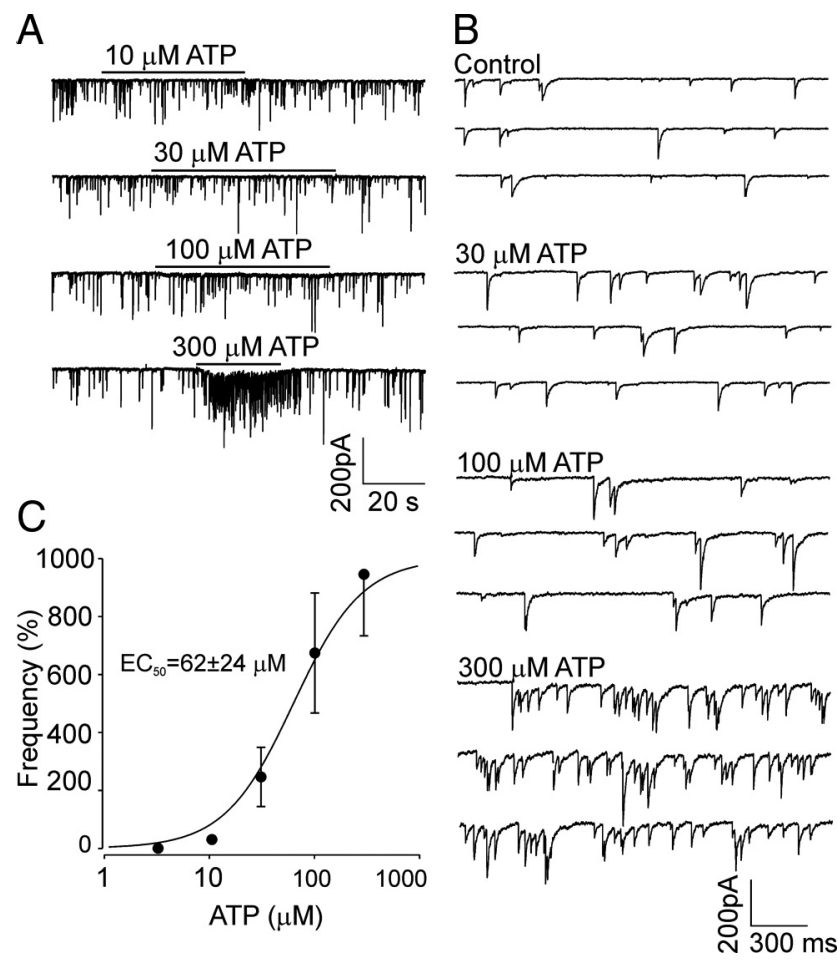

Figure 6. Dose-dependent effects of ATP. A, Representative recording of sIPSCs from SCN neurons in response to the application of ATP at different concentrations $(10,30,100$, and $300 \mu \mathrm{m}$ ) in one cell. $\boldsymbol{B}$, Traces in an expanded time scale show spontaneous synaptic currents before (Control) and after ATP application at different concentrations. C, ATP dose-response curve. Each concentration of ATP was tested on 3-5 SCN neurons. The data shown were fitted using the following equation: $\left.F=F_{M A X} /\left[1+\left(E C_{50}\right) / C\right)^{n}\right]$, where $F$ was the observed increase in frequency, $F_{M A X}$ was the maximum increase in frequency, $C$ was the ATP concentration, $E C_{50}$ was the effective concentration of ATP that produced a halfmaximal increase in frequency, and $n$ was the Hill coefficient. A theoretical curve was drawn using the following parameters: $E C_{50}=62 \mu \mathrm{M}, n=1.3$, and $F_{M A X}=945 \%$. Each point represents the mean \pm SEM.

$\mu \mathrm{M}$ ) mimicked the effects of ATP (Fig. $7 B, C$ ); the frequency increase induced by $2 \mathrm{MeS}-\mathrm{ATP}$ and ATP $\gamma \mathrm{S}$ was $105 \pm 7 \%$ and $85 \pm 20 \%$ of the ATP response, respectively (Fig. $7 D$ ).

We next tested the involvement of P2YRs. The application of ADP, 2-methylthioADP (2MeS-ADP) and adenosine 5'-O-(2thiodiiphosphate (ADP $\beta S$ ), P2Y1- and P2Y12-receptor agonists (Abbracchio et al., 2006), failed to induce a somatic current or increase the frequency of sIPSCs (Fig. 7A-C). These results indicate that the ATP-induced increases in the frequency of sIPSCs are not mediated by $\mathrm{P} 2 \mathrm{Y}$ or $\mathrm{P} 2 \mathrm{X} 7$ receptors.

In addition to the modulation of spontaneous postsynaptic currents by P2XRs agonists, we studied the effect of suramin and PPADS, which are both conventional P2XR antagonists (North, 2002; Coddou et al., 2011). Suramin (100 $\mu \mathrm{M}, 10 \mathrm{~s})$ almost completely blocked the ATP-induced response, but this antagonist alone had a strong inhibitory effect on GABAergic sIPSCs (data not shown) because this compound also inhibits GABA receptor channels (Nakazawa et al., 1995; Vavra et al., 2011). The preapplication of PPADS (10 $\mu \mathrm{M}, 30 \mathrm{~s})$ inhibited the ATP-increased frequency of sIPSCs by $71 \pm 9 \%$ (Fig. $8 A, B$ ) without affecting the amplitude (control, $45 \pm 18 \mathrm{pA}$; PPADS, $36 \pm 8 \mathrm{pA}, n=5, p>$ 0.05 ; Fig. $8 C$ ). PPADS alone had no effect on the frequency (control, $0.62 \pm 0.26 \mathrm{~Hz}$; PPADS, $0.76 \pm 0.17 \mathrm{~Hz}, n=5, p>0.05$; Fig. $8 B$ ). These results suggest that presynaptic modulation of GABAergic inhibitory synaptic transmission in the $\mathrm{SCN}$ is mediated by $\mathrm{P} 2 \mathrm{X} 2 \mathrm{R}$ because the $\mathrm{P} 2 \mathrm{X} 4 \mathrm{R}$ is relatively resistant to
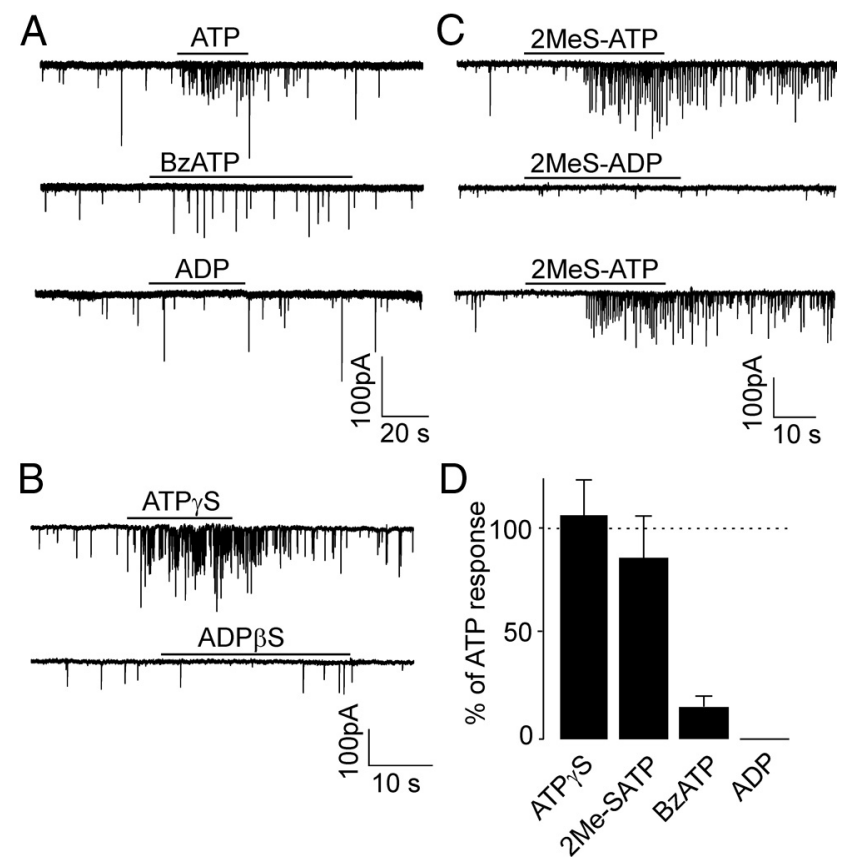

Figure 7. Agonist specificity of presynaptic responses. $A-C$, Effect on the frequency of sIPSCs induced by the application of ATP, BzATP, and ADP $(\boldsymbol{A}), \operatorname{ATP} \gamma S$ and ADP $\beta S(B)$, and 2MeS-ATP and $2 \mathrm{MeS}-\mathrm{ADP}(\boldsymbol{C})$. There is a lack of effect from agonists for P2YRs (ADP, ADP $\beta$ S, and 2MeSADP). All agonists were applied at a concentration of $100 \mu \mathrm{M}$. D, Summary histogram showing the effect of agonists for P2XRs (ATP $\gamma$ S, 2MeS-ATP, and BzATP) on the sIPSC frequency. Consequent records are from the same cells. Data are mean \pm SEM from 3 or 4 cells. The horizontal dotted line represents the effect of $100 \mu \mathrm{m}$ ATP (100\%).

suramin and PPADS (Buell et al., 1996). In addition, the lack of effect of PPADS on the basal frequency and amplitude of spontaneous postsynaptic currents indicates that endogenous ATP does not act as a spontaneously released neurotransmitter in the $\mathrm{SCN}$, but as a modulator that controls the release of other neurotransmitters.

\section{ATP-induced increase in intracellular $\mathrm{Ca}^{2+}$ levels}

The effect of ATP and agonists on the intracellular $\mathrm{Ca}^{2+}$ concentration was examined in SCN cells from fura-2 AM-loaded slices ( $n=49$ slices, $\sim 20$ cells per slice; Fig. 9). Calcium signals were obtained from somata of both neurons and glia cells, but we were not able to measure calcium changes in nerve terminals. SCN neurons and astrocytes show an increase in intracellular $\mathrm{Ca}^{2+}$ in response to glutamate, the major excitatory neurotransmitter in afferents to the SCN (van den Pol et al., 1992). We used glutamate $(100 \mu \mathrm{M})$ at the end of each experiment to calibrate the effect of ATP (Fig. 9A-D). Single-cell calcium measurements showed that ATP, ADP, BzATP, UTP, and $\alpha \beta$ me-ATP (all at $100 \mu \mathrm{M}$ ) increased the intracellular calcium concentration in $44,26,28,12$, and $11 \%$ of SCN cells, respectively (Fig. $9 E$ ). The application of UDP failed to increase the intracellular calcium. Some of the ATP-induced $\left[\mathrm{Ca}^{2+}\right]_{\mathrm{i}}$ increases were abolished after preapplication with suramin (Fig. $9 B)$ and PPADS $(50 \mu \mathrm{M} ; 52 \pm 6 \%$ inhibition; $n=64$ cells), the P2X blockers, but the P2Y inhibitor MRS2179 $(10 \mu \mathrm{M})$ had no effect in these cells (data not shown). BzATP-sensitive cells exhibited a low response to glutamate (Fig. $9 C$ ), indicating that they were most likely astrocytes (van den Pol et al., 1992). An UTP-induced increase in intracellular calcium concentration was observed in cells that were also sensitive to ADP (Fig. 9D). Although presynaptic P2XRs, potentiating neu- 
A
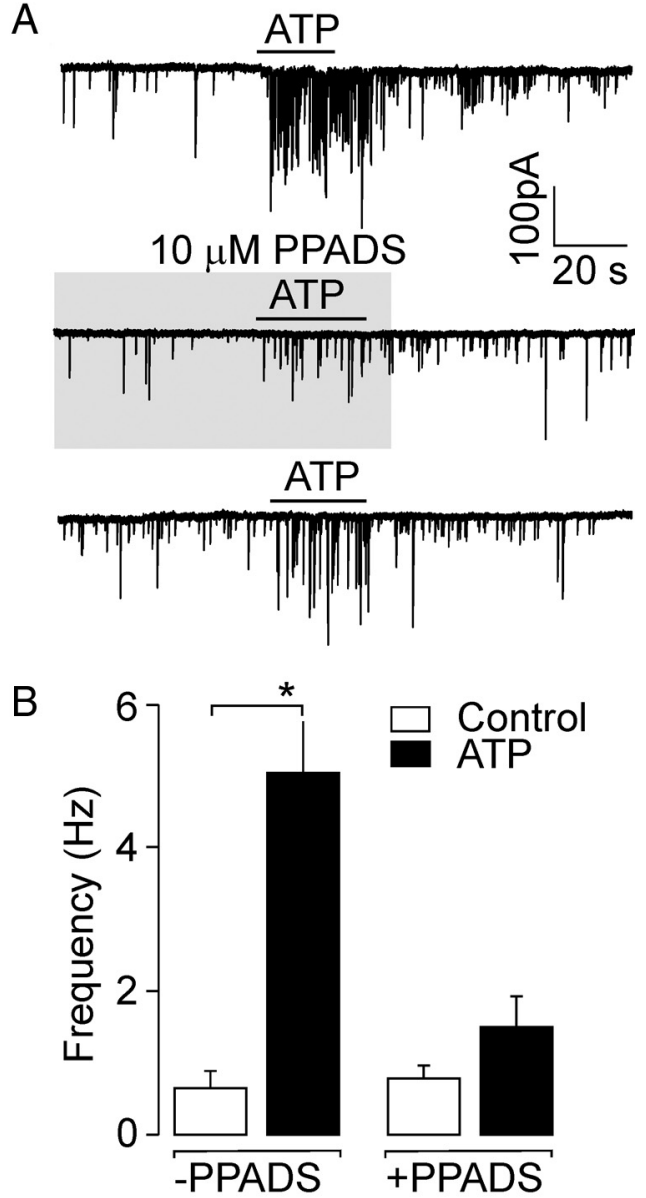

C

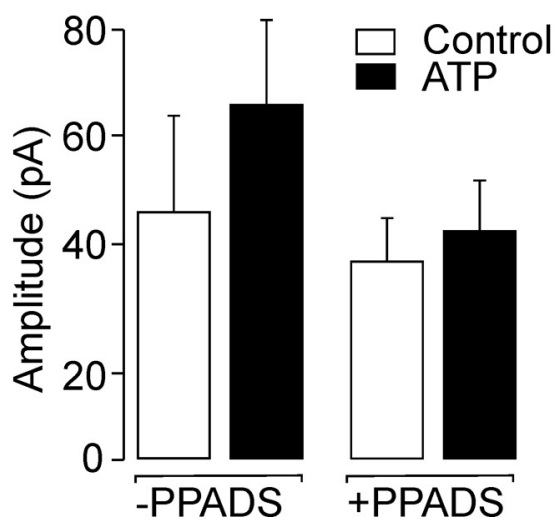

Figure 8. Inhibition of the ATP-induced response by a P2XR antagonist. $A$, Inhibition of ATP $(100 \mu \mathrm{M})$-stimulated frequency of $s$ IPSCs by the P2XR antagonist PPADS $(10 \mu \mathrm{M})$. Consequent records from the same cell are shown; the time between each ATP applications was $3-5$ min to allow recovery from PPADS-induced inhibition ( $59 \pm 19 \%$ recovery after $4 \mathrm{~min}$ ). $\boldsymbol{B}, \boldsymbol{C}$, Summary histogram showing the effect of ATP on the frequency $(\boldsymbol{B})$ and amplitude $(\boldsymbol{C})$ of sIPSCs in the presence (+PPADS) or absence (-PPADS) of PPADS. PPADS inhibited the ATP-stimulated frequency of sIPSCs but itself had no effect on the basal frequency or amplitude of sIPSCs. Data are mean \pm SEM from 3 to 5 cells. ${ }^{*} p<0.01$.

rotransmitter release, could modulate the ATP response in the slice, they are not responsible for the ATP-induced $\mathrm{Ca}^{2+}$ signals. In an experiment performed in the presence of TTX, ATP still produced $\mathrm{Ca}^{2+}$ transients in $35 \pm 6 \%$ of cells $(n=38)$. This result revealed that, in addition to the previously identified P2X2R, P2X7R and $\mathrm{P} 2 \mathrm{YRs}$ contribute to the ATP-stimulated increase of intracellular calcium levels in SCN cells.

\section{Discussion}

The major finding of this study is that ATP enhances sIPSC frequency through the presynaptic activation of P2XRs and that stimulation of P2XRs and P2YRs causes an increase in $\mathrm{Ca}^{2+}$ in SCN cells. These results are based on whole-cell patch-clamp recordings, single-cell calcium imaging, immunohistochemistry, and qRT-PCR analysis, which revealed that SCN has the capacity to express both the $\mathrm{P} 2 \mathrm{X}$ and $\mathrm{P} 2 \mathrm{Y}$ receptors and that, among all P2XRs, the P2X2 $>P 2 X 7>P 2 X 4$ mRNAs were the most abundant of the subunits, and that the P2X2R immunoreactivity colocalizes with synapsin I.

ATP increased the frequency of spontaneous GABAergic postsynaptic currents without changing the amplitude. This effect was concentration-dependent and was mimicked by the application of ATP $\gamma S$ and $2 \mathrm{MeS}-\mathrm{ATP}$ but not ADP, ADP $\beta$, and $2 \mathrm{MeS}-\mathrm{ADP}$, indicating that $\mathrm{P} 2 \mathrm{X}$ receptors are present in presynaptic nerve terminals of SCN neurons and that binding of ATP to these receptors enhances the GABA release. The effect of ATP was observed in the presence of tetrodotoxin, which inhibits action potentials. Therefore, it is likely that ATP acts by stimulating $\mathrm{Ca}^{2+}$ entry into the nerve terminals to thereby regulate GABA release. The ATP-induced response in the SCN did not desensitize and was inhibited with PPADS, which blocks homomeric P2X2 but not P2X4 receptors (North, 2002), indicating the involvement of P2X2Rs. Numerous studies have shown that $\mathrm{P} 2 \mathrm{X} 2 \mathrm{Rs}$ act presynaptically to increase glutamate and GABA release in several areas of the brain. Experiments with knock-out mice showed that $\mathrm{Ca}^{2+}$ entry through presynaptic P2X2Rs increases the frequency of spontaneous AMPA receptor-mediated glutamatergic currents in GABAergic hippocampal interneurons (Khakh et al., 2003). Inhibiting P2XRs by the application of PPADS has been shown to abolish the glutamate-dependent postsynaptic currents evoked by the focal application of ATP in dorsal horn neurons (Li et al., 1998; Nakatsuka and Gu, 2001). PPADS-sensitive P2X2Rs have been found in glutamatergic terminals of neurons in the trigeminal mesencephalic motor nucleus (Khakh and Henderson, 1998), the nucleus tractus solitari (Shigetomi and Kato, 2004), and the area postrema (Kodama et al., 2007). The presynaptic P2X2Rs underlie an increase in GABA release in a subset of GABAergic interneurons in the spinal cord (Hugel and Schlichter, 2000), Purkinje cells in rat cerebellar slices (Donato et al., 2008), and the supraoptic nuclei of hypothalamus (Vavra et al., 2011). Direct interactions between purinergic and GABAergic channel proteins have been also described (Sokolova et al., 2001; Jo et al., 2011). The present results reveal, for the first time, that the ATP-induced facilitation of GABA release in the SCN neurons is also mediated by presynaptic $\mathrm{P} 2 \mathrm{X} 2$ receptors.

Little evidence has been found for P2XR channels in the somata of SCN neurons. These channels do not appear to be expressed at functionally and immunohistochemically detectable levels on SCN neuronal cell bodies because a very small ATPevoked inward current (15 pA) was observed in only $7 \%$ of the SCN neurons and the somata of SCN cells are lacking the P2X2R immunoreactivity. Our previous study has shown that ATP application induces an inward somatic current of $\sim 125 \mathrm{pA}$ in $62 \%$ of neurons in the supraoptic nuclei (Vavra et al., 2011), which show $\mathrm{P} 2 \mathrm{X} 2$-positive immunoreactivity both on somata and nerve fibers (Loesch and Burnstock, 2001; Yao et al., 2003; Guo et al., 2009). An ATP-induced slowly inactivating inward current was also observed in isolated terminals and somata of the hypothalamic neurohypophysial system (Knott et al., 2012), and in anterior pituitary cells (Zemkova et al., 2006). Depolarization and $\mathrm{Ca}^{2+}$ influx 
stimulated by ATP have numerous functions in endocrine cells. These involve stimulation of oxytocin, vasopressin, prolactin, and luteinizing hormone secretion (Kapoor and Sladek, 2000; Stojilkovic, 2009). To the best of our knowledge, there is no information indicating that ATP could stimulate the release of neuropeptides in the SCN. Thus, even though RT-PCR analysis showed that $P 2 X 2 R$ is the most expressed subtype of ionotrophic P2XRs in the SCN, our data do not support a functional role for this receptor in the somata of SCN neurons and suggest that the expression of P2XRs is mostly limited to nerve endings in the SCN.

ATP is also viewed as a neurotransmitter that acts at postsynaptic $\mathrm{P} 2 \mathrm{X}$ receptors to mediate synaptic currents in both the peripheral nervous system (Evans et al., 1992) and the CNS (Edwards et al., 1992; Pankratov et al., 1998). We found that PPADS had no effect on the basal frequency and amplitude of sIPSC, suggesting that endogenously released ATP does not play a neurotransmitter role in the SCN but acts more as a modulator that stimulates the release of other neurotransmitters.

Our systematic RT-PCR analysis showed that $P 2 X 7$ is the second most expressed P2X subunit in the SCN. Small electrophysiological responses to the selective agonist BzATP indicate that it is unlikely that there are functional P2X7Rs in SCN nerve terminals; however, the application of BzATP caused an increase in $\mathrm{Ca}^{2+}$ in $28 \%$ of SCN cells in fura-2 AMloaded slices. The expression of this receptor is supposed to be higher in microglia than in neurons (Collo et al., 1997; DiazHernandez et al., 2008; Monif et al., 2009). Moreover, recently, several works reported the expression of functional P2X7 receptors in astrocytes (Hamilton et al., 2008; Carrasquero et al., 2009; Norenberg et al., 2011), which are present at a high density in the SCN (Morin et al., 1989), suggesting that the high mRNA level for $\mathrm{P} 2 \mathrm{X} 7$ can thus be ascribed to $\mathrm{P} 2 \mathrm{X}$ receptors expressed in non-neuronal SCN cells.

Endogenous sources of ATP for receptor stimulation may be neurons, astrocytes, or microglia (Guthrie et al., 1999; Fields and Stevens, 2000; Inoue et al., 2007). It has been shown that the ATP released by bursts of action potentials from the hypothalamic neurohypophysial system acts at $\mathrm{P} 2 \mathrm{X} 2$ receptors to modulate neuropeptide release (Custer et al., 2012). In the rat SCN, however, circadian rhythms in the ATP content are negatively correlated with electrical activity and the AVP secretion rhythm: the SCN neuronal activity and AVP release are higher during the day than during the night (Brown and Piggins, 2007), whereas the level of ATP is higher during the night (Womac et al., 2009). This finding might indicate that ATP is primarily stored and released from non-neuronal cells. Suprachi-

A
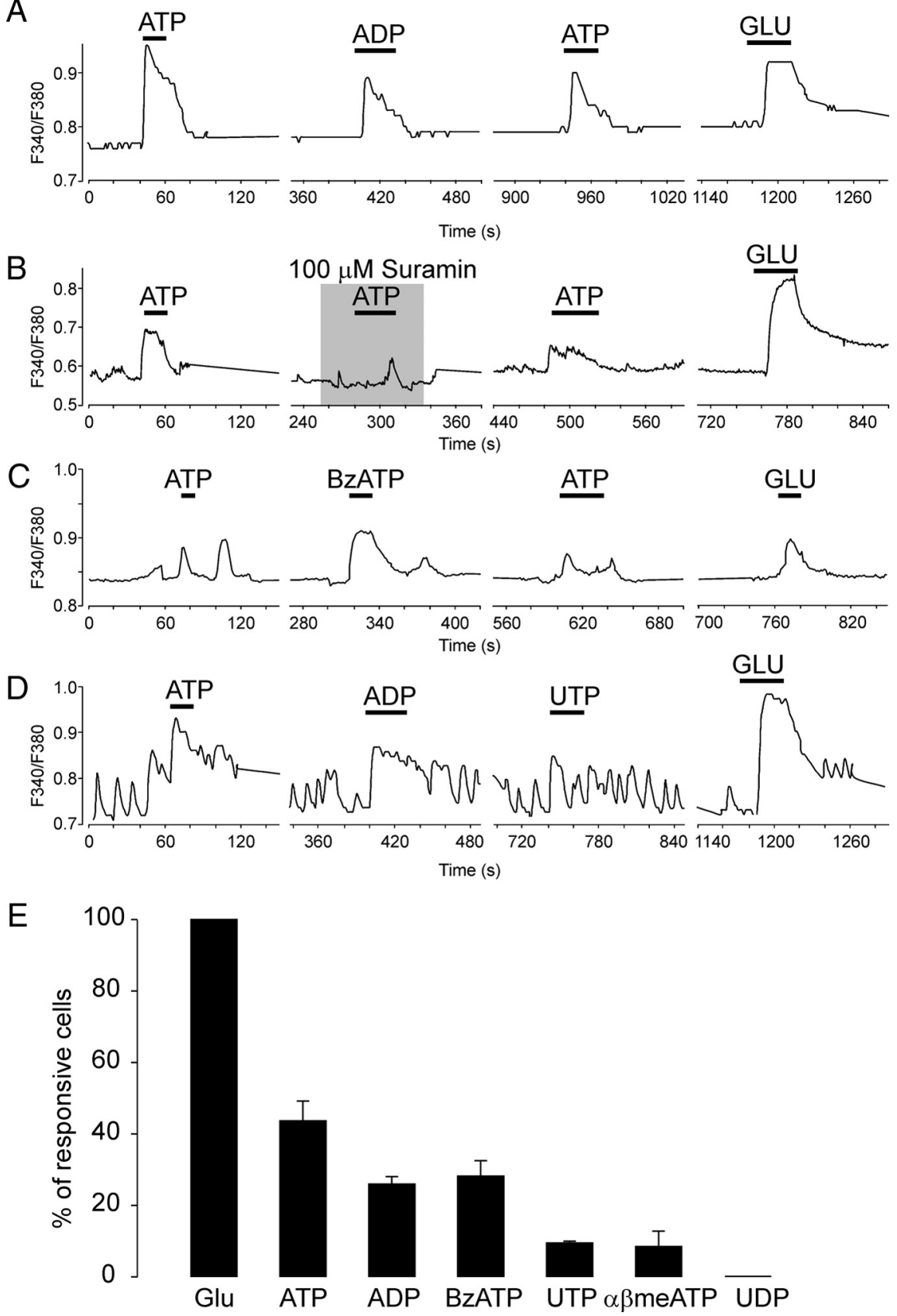

Figure 9. Calcium imaging of P2XRs and P2YRs agonists evoked responses from SCN cells in slices. $\boldsymbol{A}-\boldsymbol{D}$, Representative single-cell calcium responses to $\operatorname{ADP}(\boldsymbol{A})$, suramin $(\boldsymbol{B}), \operatorname{BzATP}(\boldsymbol{C})$, and UTP $(\boldsymbol{D})$ measured in fura-2 AM-loaded SCN slices. All agonists were applied at a concentration of $100 \mu \mathrm{M}$. ATP was applied at the beginning and glutamate (GLU; $100 \mu \mathrm{m}$ ) at the end of each experiment. Calcium

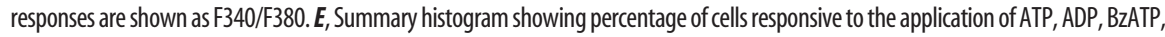
UTP, $\alpha \beta$ me-ATP, and UDP. All agonist-induced responses were related to the effect of GLU (100\%). The time between each agonist applications was 2-3 min. Measurements were performed in 49 SCN slices ( $\sim 20$ cells per slice).

asmatic nucleus astrocyte cell cultures have been shown to display intrinsic, clock gene-dependent daily rhythms in ATP release (Burkeen et al., 2011; Marpegan et al., 2011). Astrocytes releasing ATP have been found also in the hypothalamic paraventricular nucleus (Gordon et al., 2005). Thus, endogenous sources of ATP for $\mathrm{P} 2 \mathrm{X}$ receptor stimulation in the SCN are most likely glia cells.

The activation of presynaptic $\mathrm{P} 2 \mathrm{X}$ receptors by ATP raises questions about their physiological function in the SCN. As mentioned above, the firing rate of clock neurons is declining at a time when the extracellular level of ATP is increasing (Womac et al., 2009). Provided that SCN neurons might normally exert a 
GABAergic inhibitory influence on neighboring SCN neurons (Gompf et al., 2006), the increased ATP level in the SCN during the night suggests that ATP-stimulated inhibitory GABAergic synaptic transmission might contribute to the silencing of neuronal electrical activity. ATP-stimulated GABAergic transmission might also be implicated in the regulation of SCN inputs from other brain regions, for example, the anterior paraventricular thalamus (Alamilla and Aguilar-Roblero, 2010) or retina (Jiao and Rusak, 2003) that receive photic input. These regions densely innervate the ventral SCN but provide only minor innervation of the dorsal SCN (Moga and Moore, 1997). We observed that the ATP-induced increase in the frequency of sIPSCs was higher in the neurons of the VL region (52\% of cells) compared with those of the DM region (28\% of cells), suggesting that the function of presynaptic P2X receptors might be to modulate inputs that entrain the intrinsic circadian rhythms of the SCN to the external light-dark cycle. Significant differences between two SCN regions might also indicate that the expression of P2XRs in the DM is lower than in the VL. The low number of functional P2X receptors in the DM might be related to the fact that the DM region is more important in the intrinsic circadian rhytmicity of neuronal activity (Shibata et al., 1984) and apparently also in ATP rhythm (Womac et al., 2009). Thereby, DM cells would avoid undesirable regulation of the electrical activity by extracellular ATP.

In conclusion, although the PCR and immunological studies described previously (Collo et al., 1996; Xiang et al., 2006) suggest the presence of $\mathrm{P} 2 \mathrm{XRs}$ in the $\mathrm{SCN}$, no information was available regarding the means by which the activation of these channels may (or may not) lead to changes in the electrical activities of SCN cells. The present study shows that ATP activates presynaptic P2X2Rs to stimulate inhibitory synaptic transmission within the SCN and that this effect varies between regions. Nonetheless, the molecular and neurochemical mechanisms underlying ATP effects likely involve multiple purinergic receptor systems (P2X and P2Y). Thus, extracellular ATP together with its receptors comprise a new excitatory system that may be involved in the regulation of the electrical activity of circadian pacemaker cells.

\section{References}

Abbracchio MP, Burnstock G, Boeynaems JM, Barnard EA, Boyer JL, Kennedy C, Knight GE, Fumagalli M, Gachet C, Jacobson KA, Weisman GA (2006) International Union of Pharmacology LVIII: update on the P2Y G protein-coupled nucleotide receptors: from molecular mechanisms and pathophysiology to therapy. Pharmacol Rev 58:281-341. CrossRef Medline

Abbracchio MP, Burnstock G, Verkhratsky A, Zimmermann H (2009) Purinergic signalling in the nervous system: an overview. Trends Neurosci 32:19-29. CrossRef Medline

Alamilla J, Aguilar-Roblero R (2010) Glutamate and GABA neurotransmission from the paraventricular thalamus to the suprachiasmatic nuclei in the rat. J Biol Rhythms 25:28-36. CrossRef Medline

Brown TM, Piggins HD (2007) Electrophysiology of the suprachiasmatic circadian clock. Prog Neurobiol 82:229-255. CrossRef Medline

Buell G, Lewis C, Collo G, North RA, Surprenant A (1996) An antagonist-insensitive $\mathrm{P} 2 \mathrm{X}$ receptor expressed in epithelia and brain. EMBO J 15:55-62. Medline

Burkeen JF, Womac AD, Earnest DJ, Zoran MJ (2011) Mitochondrial calcium signaling mediates rhythmic extracellular ATP accumulation in suprachiasmatic nucleus astrocytes. J Neurosci 31:8432-8440. CrossRef Medline

Burnstock G (1977) The purinergic nerve hypothesis. Ciba Found Symp 48:295-314. Medline

Carrasquero LM, Delicado EG, Bustillo D, Gutiérrez-Martin Y, Artalejo AR, Miras-Portugal MT (2009) P2X7 and P2Y13 purinergic receptors mediate intracellular calcium responses to BzATP in rat cerebellar astrocytes. J Neurochem 110:879-889. CrossRef Medline
Cheng MY, Bullock CM, Li C, Lee AG, Bermak JC, Belluzzi J, Weaver DR, Leslie FM, Zhou QY (2002) Prokineticin 2 transmits the behavioural circadian rhythm of the suprachiasmatic nucleus. Nature 417:405-410. CrossRef Medline

Coddou C, Stojilkovic SS, Huidobro-Toro JP (2011) Allosteric modulation of ATP-gated P2X receptor channels. Rev Neurosci 22:335-354. CrossRef Medline

Collo G, North RA, Kawashima E, Merlo-Pich E, Neidhart S, Surprenant A, Buell G (1996) Cloning of P2X5 and P2X6 receptors and the distribution and properties of an extended family of ATP-gated ion channels. J Neurosci 16:2495-2507. Medline

Collo G, Neidhart S, Kawashima E, Kosco-Vilbois M, North RA, Buell G (1997) Tissue distribution of the P2X7 receptor. Neuropharmacology 36:1277-1283. CrossRef Medline

Custer EE, Knott TK, Cuadra AE, Ortiz-Miranda S, Lemos JR (2012) P2X purinergic receptor knockout mice reveal endogenous ATP modulation of both vasopressin and oxytocin release from the intact neurohypophysis. J Neuroendocrinol 24:674-680. CrossRef Medline

Díaz-Hernandez M, del Puerto A, Díaz-Hernandez JI, Diez-Zaera M, Lucas JJ, Garrido JJ, Miras-Portugal MT (2008) Inhibition of the ATP-gated $\mathrm{P} 2 \mathrm{X} 7$ receptor promotes axonal growth and branching in cultured hippocampal neurons. J Cell Sci 121:3717-3728. CrossRef Medline

Dibner C, Schibler U, Albrecht U (2010) The mammalian circadian timing system: organization and coordination of central and peripheral clocks. Annu Rev Physiol 72:517-549. CrossRef Medline

Dittert I, Benedikt J, Vyklický L, Zimmermann K, Reeh PW, Vlachová V (2006) Improved superfusion technique for rapid cooling or heating of cultured cells under patch-clamp conditions. J Neurosci Methods 151: 178-185. CrossRef Medline

Donato R, Rodrigues RJ, Takahashi M, Tsai MC, Soto D, Miyagi K, Villafuertes RG, Cunha RA, Edwards FA (2008) GABA release by basket cells onto Purkinje cells, in rat cerebellar slices, is directly controlled by presynaptic purinergic receptors, modulating $\mathrm{Ca}^{2+}$ influx. Cell Calcium 44 : 521-532. CrossRef Medline

Edwards FA, Gibb AJ, Colquhoun D (1992) ATP receptor-mediated synaptic currents in the central nervous system. Nature 359:144-147. CrossRef Medline

Evans RJ, Derkach V, Surprenant A (1992) ATP mediates fast synaptic transmission in mammalian neurons. Nature 357:503-505. CrossRef Medline

Fields RD, Stevens B (2000) ATP: an extracellular signaling molecule between neurons and glia. Trends Neurosci 23:625-633. CrossRef Medline

Gillette MU, Reppert SM (1987) The hypothalamic suprachiasmatic nuclei: circadian patterns of vasopressin secretion and neuronal activity in vitro. Brain Res Bull 19:135-139. CrossRef Medline

Gompf HS, Irwin RP, Allen CN (2006) Retrograde suppression of GABAergic currents in a subset of SCN neurons. Eur J Neurosci 23:3209-3216. CrossRef Medline

Gordon GR, Baimoukhametova DV, Hewitt SA, Rajapaksha WR, Fisher TE, Bains JS (2005) Norepinephrine triggers release of glial ATP to increase postsynaptic efficacy. Nat Neurosci 8:1078-1086. CrossRef Medline

Gourine AV, Melenchuk EV, Poputnikov DM, Gourine VN, Spyer KM (2002) Involvement of purinergic signalling in central mechanisms of body temperature regulation in rats. Br J Pharmacol 135:2047-2055. CrossRef Medline

Guo W, Sun J, Xu X, Bunstock G, He C, Xiang Z (2009) P2X receptors are differentially expressed on vasopressin- and oxytocin-containing neurons in the supraoptic and paraventricular nuclei of rat hypothalamus. Histochem Cell Biol 131:29-41. CrossRef Medline

Guthrie PB, Knappenberger J, Segal M, Bennett MV, Charles AC, Kater SB (1999) ATP released from astrocytes mediates glial calcium waves. J Neurosci 19:520-528. Medline

Hallworth R, Cato M, Colbert C, Rea MA (2002) Presynaptic adenosine Al receptors regulate retinohypothalamic neurotransmission in the hamster suprachiasmatic nucleus. J Neurobiol 52:230-240. CrossRef Medline

Hamilton N, Vayro S, Kirchhoff F, Verkhratsky A, Robbins J, Gorecki DC, Butt AM (2008) Mechanisms of ATP- and glutamate-mediated calcium signaling in white matter astrocytes. Glia 56:734-749. CrossRef Medline

Hugel S, Schlichter R (2000) Presynaptic P2X receptors facilitate inhibitory GABAergic transmission between cultured rat spinal cord dorsal horn neurons. J Neurosci 20:2121-2130. Medline

Inoue K, Koizumi S, Tsuda M (2007) The role of nucleotides in the neuron- 
glia communication responsible for the brain functions. J Neurochem 102:1447-1458. CrossRef Medline

Inouye ST, Kawamura H (1979) Persistence of circadian rhythmicity in a mammalian hypothalamic island containing the suprachiasmatic nucleus. Proc Natl Acad Sci U S A 76:5962-5966. CrossRef Medline

Jiang ZG, Allen CN, North RA (1995) Presynaptic inhibition by baclofen of retinohypothalamic excitatory synaptic transmission in rat suprachiasmatic nucleus. Neuroscience 64:813-819. CrossRef Medline

Jiao YY, Rusak B (2003) Electrophysiology of optic nerve input to suprachiasmatic nucleus neurons in rats and degus. Brain Res 960:142-151. CrossRef Medline

Jo YH, Donier E, Martinez A, Garret M, Toulme E, Boue-Grabot E (2011) Cross-talk between P2X4 and GABA-A receptors determines synaptic efficacy at central synapses. J Biol Chem 288:19993-20004. CrossRef Medline

Kanjhan R, Housley GD, Burton LD, Christie DL, Kippenberger A, Thorne PR, Luo L, Ryan AF (1999) Distribution of the P2X2 receptor subunit of the ATP-gated ion channels in the rat central nervous system. J Comp Neurol 407:11-32. CrossRef Medline

Kapoor JR, Sladek CD (2000) Purinergic and adrenergic agonists synergize in stimulating vasopressin and oxytocin release. J Neurosci 20:8868-8875. Medline

Khakh BS, Henderson G (1998) ATP receptor-mediated enhancement of fast excitatory neurotransmitter release in the brain. Mol Pharmacol 54: 372-378. Medline

Khakh BS, Gittermann D, Cockayne DA, Jones A (2003) ATP modulation of excitatory synapses onto interneurons. J Neurosci 23:7426-7437. Medline

Kim YI, Dudek FE (1992) Intracellular electrophysiological study of suprachiasmatic nucleus neurons in rodents: inhibitory synaptic mechanisms. J Physiol 458:247-260. Medline

Klein DC, Moore RY, Reppert SM (1991) Suprachiasmatic nucleus. In: The mind's clock. New York: Oxford UP.

Knott TK, Hussy N, Cuadra AE, Lee RH, Ortiz-Miranda S, Custer EE, Lemos JR (2012) Adenosine trisphosphate appears to act via different receptors in terminals versus somata of the hypothalamic neurohypophysial system. J Neuroendocrinol 24:681-689. CrossRef Medline

Kodama N, Funahashi M, Mitoh Y, Minagi S, Matsuo R (2007) Purinergic modulation of area postrema neuronal excitability in rat brain slices. Brain Res 1165:50-59. CrossRef Medline

Kretschmannova K, Svobodova I, Zemkova H (2003) Day-night variations in zinc sensitivity of GABAA receptor-channels in rat suprachiasmatic nucleus. Brain Res Mol Brain Res 120:46-51. CrossRef Medline

Li P, Calejesan AA, Zhuo M (1998) ATP P2x receptors and sensory synaptic transmission between primary afferent fibers and spinal dorsal horn neurons in rats. J Neurophysiol 80:3356-3360. Medline

Loesch A, Burnstock G (2001) Immunoreactivity to P2X(6) receptors in the rat hypothalamo-neurohypophysial system: an ultrastructural study with extravidin and colloidal gold-silver labelling. Neuroscience 106:621-631. CrossRef Medline

Marpegan L, Swanstrom AE, Chung K, Simon T, Haydon PG, Khan SK, Liu AC, Herzog ED, Beaulé C (2011) Circadian regulation of ATP release in astrocytes. J Neurosci 31:8342-8350. CrossRef Medline

Mitome M, Shirakawa T, Oshima S, Nakamura W, Oguchi H (2001) Circadian rhythm of nitric oxide production in the dorsal region of the suprachiasmatic nucleus in rats. Neurosci Lett 303:161-164. CrossRef Medline

Moga MM, Moore RY (1997) Organization of neural inputs to the suprachiasmatic nucleus in the rat. J Comp Neurol 389:508-534. CrossRef Medline

Monif M, Reid CA, Powell KL, Smart ML, Williams DA (2009) The P2X7 receptor drives microglial activation and proliferation: a trophic role for P2X7R pore. J Neurosci 29:3781-3791. CrossRef Medline

Moore RY, Speh JC, Leak RK (2002) Suprachiasmatic nucleus organization. Cell Tissue Res 309:89-98. CrossRef Medline

Morin LP, Johnson RF, Moore RY (1989) Two brain nuclei controlling circadian rhythms are identified by GFAP immunoreactivity in hamsters and rats. Neurosci Lett 99:55-60. CrossRef Medline

Nakatsuka T, Gu JG (2001) ATP P2X receptor-mediated enhancement of glutamate release and evoked EPSCs in dorsal horn neurons of the rat spinal cord. J Neurosci 21:6522-6531. Medline

Nakazawa K, Inoue K, Ito K, Koizumi S, Inoue K (1995) Inhibition by suramin and reactive blue 2 of GABA and glutamate receptor channels in rat hippocampal neurons. Naunyn Schmiedebergs Arch Pharmacol 351: 202-208. Medline

Nörenberg W, Schunk J, Fischer W, Sobottka H, Riedel T, Oliveira JF, Franke $\mathrm{H}$, Illes P (2010) Electrophysiological classification of P2X7 receptors in rat cultured neocortical astroglia. Br J Pharmacol 160:1941-1952. CrossRef Medline

North RA (2002) Molecular physiology of P2X receptors. Physiol Rev 82: 1013-1067. Medline

Pankratov Y, Castro E, Miras-Portugal MT, Krishtal O (1998) A purinergic component of the excitatory postsynaptic current mediated by P2X receptors in the CA1 neurons of the rat hippocampus. Eur J Neurosci 10: 3898-3902. CrossRef Medline

Peytevin J, Aïoun J, Chambille I (2000) Neurons that express the AMPA receptor GluR2/3 subunits in suprachiasmatic nuclei of Syrian hamsters colocalize either vasoactive intestinal peptide, peptide histidine isoleucine or gastrin-releasing peptide. Cell Tissue Res 300:345-359. CrossRef Medline

Schwartz WJ, Reppert SM (1985) Neural regulation of the circadian vasopressin rhythm in cerebrospinal fluid: a pre-eminent role for the suprachiasmatic nuclei. J Neurosci 5:2771-2778. Medline

Schwartz WJ, Davidsen LC, Smith CB (1980) In vivo metabolic activity of a putative circadian oscillator, the rat suprachiasmatic nucleus. J Comp Neurol 189:157-167. CrossRef Medline

Shibata S, Liou S, Ueki S, Oomura Y (1984) Influence of environmental light-dark cycle and enucleation on activity of suprachiasmatic neurons in slice preparations. Brain 302:75-81. CrossRef Medline

Shigetomi E, Kato F (2004) Action potential-independent release of glutamate by $\mathrm{Ca}^{2+}$ entry through presynaptic $\mathrm{P} 2 \mathrm{X}$ receptors elicits postsynaptic firing in the brainstem autonomic network. J Neurosci 24:3125-3135. CrossRef Medline

Shinohara K, Honma S, Katsuno Y, Abe H, Honma K (1994) Circadian rhythms in the release of vasoactive intestinal polypeptide and argininevasopressin in organotypic slice culture of rat suprachiasmatic nucleus. Neurosci Lett 170:183-186. CrossRef Medline

Sigworth LA, Rea MA (2003) Adenosine A1 receptors regulate the response of the mouse circadian clock to light. Brain Res 960:246-251. CrossRef Medline

Sokolova E, Nistri A, Giniatullin R (2001) Negative cross talk between anionic GABAA and cationic P2X ionotropic receptors of rat dorsal root ganglion neurons. J Neurosci 21:4958-4968. Medline

Stojilkovic SS (2009) Purinergic regulation of hypothalamopituitary functions. Trends Endocrinol Metab 20:460-468. CrossRef Medline

Troadec JD, Thirion S, Nicaise G, Lemos JR, Dayanithi G (1998) ATPevoked increases in $\left[\mathrm{Ca}^{2+}\right] \mathrm{i}$ and peptide release from rat isolated neurohypophysial terminals via a P2X2 purinoceptor. J Physiol 511:89-103. CrossRef Medline

van den Pol AN (1993) Glutamate and GABA presence and action in the suprachiasmatic nucleus. J Biol Rhythms 8:S11-S15. Medline

van den Pol AN, Finkbeiner SM, Cornell-Bell AH (1992) Calcium excitability and oscillations in suprachiasmatic nucleus neurons and glia in vitro. J Neurosci 12:2648-2664. Medline

Vavra V, Bhattacharya A, Zemkova H (2011) Facilitation of glutamate and GABA release by $\mathrm{P} 2 \mathrm{X}$ receptor activation in supraoptic neurons from freshly isolated rat brain slices. Neuroscience 188:1-12. CrossRef Medline

Vulchanova L, Arvidsson U, Riedl M, Wang J, Buell G, Surprenant A, North RA, Elde R (1996) Differential distribution of two ATP-gated channels (P2X receptors) determined by immunocytochemistry. Proc Natl Acad Sci U S A 93:8063-8067. CrossRef Medline

Watanabe K, Koibuchi N, Ohtake H, Yamaoka S (1993) Circadian rhythms of vasopressin release in primary cultures of rat suprachiasmatic nucleus. Brain Res 624:115-120. CrossRef Medline

Watanabe K, Vanecek J, Yamaoka S (2000) In vitro entrainment of the circadian rhythm of vasopressin-releasing cells in suprachiasmatic nucleus by vasoactive intestinal polypeptide. Brain Res 877:361-366. CrossRef Medline

Womac AD, Burkeen JF, Neuendorff N, Earnest DJ, Zoran MJ (2009) Circadian rhythms of extracellular ATP accumulation in suprachiasmatic nucleus cells and cultured astrocytes. Eur J Neurosci 30:869-876. CrossRef Medline

Xiang Z, He C, Burnstock G (2006) P2X5 receptors are expressed on neurons containing arginine vasopressin and nitric oxide synthase in the rat hypothalamus. Brain Res 1099:56-63. CrossRef Medline 
Yamazaki S, Ishida Y, Inouye S (1994) Circadian rhythms of adenosine triphosphate contents in the suprachiasmatic nucleus, anterior hypothalamic area and caudate putamen of the rat: negative correlation with electrical activity. Brain Res 664:237-240. CrossRef Medline

Yao ST, Gourine AV, Spyer KM, Barden JA, Lawrence AJ (2003) Localisation of $\mathrm{P} 2 \mathrm{X} 2$ receptor subunit immunoreactivity on nitric oxide synthase expressing neurones in the brainstem and hypothalamus of the rat: a fluorescence immunohistochemical study. Neuroscience 121:411-419. CrossRef Medline

Zemkova H, Balik A, Jiang Y, Kretschmannova K, Stojilkovic SS (2006) Roles of purinergic $\mathrm{P} 2 \mathrm{X}$ receptors as pacemaking channels and modulators of calcium-mobilizing pathway in pituitary gonadotrophs. Mol Endocrinol 20:1423-1436. CrossRef Medline 